\title{
Liturgi dan Keutuhan Ciptaan
}

\author{
Stenly Vianny Pondaag \\ Sekolah Tinggi Filsafat Seminari Pineleng \\ Stenly_Pondaag@stfsp.ac.id
}

\begin{abstract}
The essay deals with the relationship between liturgy und integrity of creation. It aims at providing a liturgical and theological explanation to the question: whether the Christian liturgy can contribute to the global movement regarding the integrity of creation. This study analyses theologically some selected eucharistic prayer texts in which the praise of God the Creator and of his works of creation occur. This study shows us that the theme of creation was an integral part of ancient Christian eucharistic prayers, and it remains the important element of the eucharistic prayers in the new time. The introduction of the theme of creation into the new eucharistic prayers in Roman Missal 1970 was one of the visible fruits of the eucharistic prayer reform after the second Vatican council. On the one hand, it expresses the new awareness of the richness of ancient liturgical tradition. On the other hand, the motif of creation has a close relevance to the hope and concern of our times. It should offer us a theological and liturgical inspiration in developing an ethical awareness and human responsibility toward the integration of creation.
\end{abstract}

\section{Keywords:}

Keutuhan Ciptaan, Anafora, Doa Syukur Agung, Motif Penciptaan, oratio theologica, oratio oeconomica, pertobatan ekologis.

\section{PENDAHULUAN}

Di tengah ancaman krisis ekologi dan seiring dengan gencarnya kampanye global penyelamatan bumi, Gereja menyadari bahwa tanggung jawab ekologis merupakan bagian yang tak terpisahkan dari misi evangelisasi baru. Atas pelbagai cara Gereja berupaya untuk mengintegrasikan tanggung jawab ekologis itu ke dalam program pewartaan dan katekese. Salah satu contoh adalah Bulan Kitab Suci Nasional 2019 yang mengusung tema Mewartakan Ka- 
bar Baik di Tengah Krisis Lingkungan Hidup. ${ }^{1}$ Inspirasi dasar dari tema ini adalah ensiklik Paus Fransiskus tentang merawat rumah kita bersama Laudato Si (24 Mei 2015). Menurut Paus, bumi ini bagaikan saudari yang hidup bersamasama dengan kita; bumi bagaikan ibu yang mengasuh kita, tetapi ibu itu sedang menjerit dalam penderitaan. Krisis lingkungan hidup adalah jeritan ibu bumi yang terluka oleh keserakahan anak-anaknya. Di dalam bulan kitab suci nasional ini, umat Katolik Indonesia diajak untuk merenungkan inspirasiinspirasi ekologis dari Kitab Suci demi membangun integritas ciptaan. Ini hanyalah salah satu dari sekian contoh bagaimana Gereja menyadari tanggung jawabnya atas masa depan bumi ciptaan Allah yang sedang terancam oleh krisis. Teologi penciptaan adalah inspirasi dasar bagi Gereja untuk menggali makna dan tujuan asali dari relasi antara pencipta dan seluruh ciptaan.

Tulisan ini hendak merefleksikan tanggung jawab ekologis manusia terhadap keutuhan ciptaan dari perspektif liturgi. Pertanyaan dasar yang hendak dijawab adalah apakah perayaan liturgi bisa memberikan inspirasi bagi pemahaman dan perilaku manusia untuk menjaga keutuhan ciptaan? Di tengah krisis ekologis, apa sumbangan liturgi demi mewujudkan pertobatan ekologis dan perubahan hati? Tulisan ini bertujuan untuk menganalisa teksteks liturgi dan menemukan gagasan-gagasan teologis di balik teks yang inspiratif bagi pemeliharaan keutuhan ciptaan. Uraian ini juga bermaksud untuk menyumbang gagasan bagi pengembangan kesadaran perilaku etis antara manusia dengan ciptaan dan juga bagi keutuhan ciptaan.

\section{METODE}

Untuk menjawab pertanyaan penelitian di atas, maka penulis menggunakan metode analisa teks dan tinjauan literatur. Fokus analisa adalah teks-teks Doa Syukur Agung (selanjutnya disingkat DSA) atau anafora yang memuat gagasan atau motif penciptaan. Analisa teks bekerja secara hermeneutis. Artinya bahwa analisa ini terarah pada penemuan makna teologis di balik teks tersebut. Analisa teks akan dibantu dengan literatur-literatur yang pernah membahas tentang tema yang sama.

Tentu saja penulis harus membatasi teks-teks DSA yang akan menjadi objek analisa. Pertama-tama penulis mengarahkan pandangan pada dua teks penting yang menjadi akar dari DSA ataua anafora, yakni teks birkat ha-mazon (Doa Se-

1 Bdk. “Mewartakan Kabar Baik di Tengah Krisis Lingkungan Hidup”. Bulan Kitab Suci Nasional (Jakarta: Lembaga Biblika Indonesia, 2019), hal. 10 dst. 
sudah Makan Yahudi) dan teks Didache 10 (Teks Doa Sesudah Makan jemaat Kristen awal). Kemudian, penulis juga akan menganalisa dua contoh teks anafora klasik yang memainkan peranan yang sangat penting dalam ekaristi Liturgi Timur sampai sekarang ini, yakni Anafora St. Yakobus versi Yahudi dan Anafora St. Basilius versi Alexandria. Tak kalah pentingnya adalah analisa teks DSA baru dalam Missale Romanum 1970, yakni DSA II, III dan IV. Pada bagian akhir penulis juga menampilkan teks DSA asli Indonesia yang tidak pernah disahkan oleh Vatikan, yakni DSA Indonesia Tercinta.

\section{HASIL DAN PEMBAHASAN}

Dalam uraian ini kita menggunakan terminologi motif penciptaan sebagai kunci hermeneutis untuk mengerti relasi antara liturgi dengan keutuhan ciptaan. Motif penciptaan dalam Doa Syukur Agung sudah didiskusikan oleh beberapa pengarang, seperti Joseph Keenan ${ }^{2}$, Manfred Probst ${ }^{3}$, Thomas Talley ${ }^{4}$ dan Jörg Müller ${ }^{5}$. Menurut Josef Keenan, penerimaan tema penciptaan dalam DSA merupakan the advent of new eucharistic prayer. ${ }^{6}$ Harus diakui bahwa selama berabad-abad anamnesis karya penciptaan Allah termarginalkan dalam liturgi Gereja Katolik Roma. Canon Romanus (DSA I) sebagai satu-satunya DSA yang berlaku dalam Missale Romanum sejak Pius V (Missale Romanum 1570) tidak memberi tempat pada syukur atas ciptaan Allah. Jika motif ini diangkat dalam DSA yang baru dalam Missale Romanum 1970, maka pertanyaannya adalah apakah ini sebuah inovasi liturgis? Untuk menjawab pertanyaan tersebut, kita akan melayangkan padangan pada akar DSA dalam tradisi Yahudi dan kekristenan awal.

\section{Birkat Ha-mazon (Doa Sesudah Makan Orang Yahudi)}

Dalam tradisi perjamuan Yahudi, sesudah makan kepala keluarga mendasarkan doa berkat atas makanan, atau biasa disebut birkat ha-mazon. Menurut Jasper dan Cuming, doa ini memberikan pengaruh yang sangat besar

2 Bdk. Joseph Keenan, "The Importance of the Creation Motif in an Eucharistic Prayer", Worship 53 (1978).

3 Bdk. Manfred Probst, "Das Schöpfungsmotiv im Eucharistischen Hochgebet", Liturgisches Jahrbuch 3 (1981).

4 Bdk. Thomas J. Talley, “The Creation Theme in Eucharistic Prayer”, dalam Creation and Liturgy (In Honor of H. Boone Porter), ed. Ralph N. McMichael Jr. (Washington, 1993).

5 Bdk. Jörg Müller, “Das Leben neu geschaffen. Das Ineinander von Schöpfung und Erlösung im Eucharistischen Hochgebet", Heiliger Dienst 71 (2017).

6 Bdk. Keenan, “The Importance”, hal. 341. 
bagi pembentukan DSA kristiani. ${ }^{7}$ Doa Sesudah Makan Yahudi ini terdiri dari tiga paragraf singkat. Masing-masing dimulai dengan rumusan pembuka dan ditutup dengan rumusan penutup (chatimah). Paragraf pertama berisikan pujian kepada Tuhan Sang Pencipta atas pemberian makanan. Paragraf kedua adalah syukur atas pemberian tanah, perjanjian dan Hukum Taurat. Paragraf ketiga adalah sebuah permohonan untuk pembangunan Yerusalem pada akhir sejarah. Menurut Josef Heinemann, ketiga tema tersebut bersesuaian dengan motif-motif yang sangat dominan dalam liturgi Yahudi, yakni motif penciptaan, pewahyuan dan penyelamatan. ${ }^{8}$

Salah satu versi teks birkat ha-mazon terdapat dalam buku doa (Siddur) dari Rabi Saadja Gaon (akhir abad pertama). Teks doanya adalah sebagai berikut: ${ }^{9}$

[Pujian] Terpujilah Engkau, Tuhan Allah kami, penguasa semesta alam, yang memberi makan kepada seluruh alam ciptaan dengan kebaikan, berkat, dan kemurahan hati. Terpujilah Engkau, yang memberi makan kepada semua.

[Syukur] Kami mengucap syukur kepada-Mu Tuhan Allah kami, karena Engkau memberikan kepada kami sebagai milik tanah yang baik, luas dan menyenangkan, perjanjian, hukum, hidup dan makanan. Untuk semuanya itu, kami mengucap syukur kepada-Mu dan memuji nama-Mu selamalamanya. Terpujilah Engkau ya Tuhan atas tanah dan makanan.

[Permohonan] Kasihanilah umat-Mu Israel, ya Tuhan Allah kami, kota kami Yerusalem, Bait Allah kami dan tempat kediaman-Mu, dan Sion tempat peristirahatan-Mu, dan rumah-Mu yang besar dan kudus di atasnya namaMu diserukan. Dan semoga di tempat itu Engkau membaharui kembali kerajaan keluarga Daud di masa-masa kami ini, dan bangunlah Yerusalem segera. Terpujilah Engkau Tuhan yang membangun Yerusalem.

Birkat ha-mazon memainkan peranan yang sangat penting dalam pembentukan dan perkembangan awal DSA. Bahkan, teks doa ini menjadi inspirasi dasar pembentukan teks Doa Pengunjukan Bahan Persembahan dalam Missale Romanum $1970 .{ }^{10}$ Tiga elemen dasar Doa Syukur Agung sekarang ini,

7 R.C.D. Jasper and G.J. Cuming, Prayer of the Eucharist. Early and Reformed (Collegeville: Liturgical Press, 1990), hal. 7.

8 Bdk. Joseph Heinemann, Prayer in the Talmud. Form and Patterns (Berlin: De Gruyter, 1977), hal. 33.

9 Bdk. Reinhard Meßner, Einführung in die Liturgiewissenschaft, cet. ke- 2 (Padernorn: Ferdinand Schöningh, 2009), hal. 155.

${ }^{10}$ Doa Pengunjukan Bahan Persembahan untuk roti berbunyi sebagai berikut: "Terpujilah Engkau ya Tuhan, Allah semesta alam, sebab dari kemurahan-Mu kami menerima roti yang 
yakni pujian, ucapan syukur dan permohonan, kemungkinan berdasar pada birkat ha-mazon. Pokok penting yang hendak diangkat di sini adalah motif penciptaan dari birkat ha-mazon ini. Paragraf pertama menampilkan motif sebenarnya dari doa pujian, yakni Allah sebagai pencipta yang memberi makan kepada seluruh ciptaan-Nya. Rahmat Allah berupa makanan menunjukkan perhatian Allah bagi seluruh ciptaan. Dengan demikian doa ini mengingatkan umat yang berdoa akan makanan sebagai pemberian yang diterima dari tangan Sang Pencipta. Mereka yang mengambil bagian dalam perjamuan makan sekaligus juga dipersatukan dengan seluruh ciptaan dan dengan Sang Pencipta sendiri.

\section{Doa Sesudah Makan di dalam Didache}

Didache merupakan salah satu tata Gereja kekristenan awal dan muncul sekitar abad ke-2 di wilayah Palestina-Suriah. Tulisan ini memberikan kesaksian penting tentang perjamuan ekaristi jemaat Kristen awal. Di dalam Didache ini terdapat dua doa pokok perayaan perjamuan ekaristi jemaat Kristen awal, yakni doa untuk perjamuan (doa sebelum makan) dan doa syukur sesudah perjamuan. ${ }^{11}$ Doa-doa ini memiliki peranan penting pada fase awal pembentukan doa ekaristi atau kemudian dikenal dengan Doa Syukur Agung.

Perhatian kita terutama diarahkan pada Doa Syukur sesudah makan (Did 10:2-6). Doa Syukur ini memiliki kemiripan dengan doa makan (birkat ma-mazon) dari tradisi Yahudi. Kedekatan antara keduanya terletak terutama pada motif penciptaan. Oleh karena itu, ada anggapan bahwa Doa Syukur dalam Didache disusun berdasar pada birkat ha-mazon. Namun, nuansa kristiani sudah sangat kental di dalam Doa Syukur tersebut. Hal ini tampak jelas dalam kata kunci

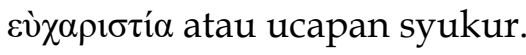

Doa Syukur (Did 10:1-4): $:^{12}$

10.1 Sesudah kenyang ucapkanlah syukur sebagai berikut:

2. Kami bersyukur kepada-Mu Bapa yang kudus, demi nama-Mu yang kudus

kami siapkan ini. Inilah hasil dari bumi dan usaha manusia yang bagi kami akan menjadi roti kehidupan" (TPE, hal. 37). Untuk anggur adalah sebagai berikut: "Terpujilah Engkau yang Tuhan, Allah semesta alam, sebab dari kemurahan-Mu kami menerima anggur yang kami siapkan ini. Inilah hasil dari pohon anggur dan usaha manusia yang bagi kami akan menjadi minuman rohani" (TPE, hal. 38).

${ }^{11}$ Bdk. Kurt Niederwimmer, Didache (Göttingen: Vandenkoeck, 1989), hal. 193.

${ }_{12}$ Bdk. Niederwimmer, Didache, hal. 193. 
yang Engkau perkenankan tinggal di dalam hati kami, dan bagi pengetahuan, iman dan kekekalan yang telah Engkau wahyukan kepada kami melalui Yesus hamba-Mu. Pujian bagi-Mu sepanjang segala masa.

3. Engkau, Tuhan penguasa segala sesuatu, telah menciptakan segala sesuatu demi nama-Mu; Engkau telah memberikan kepada manusia makanan dan minuman untuk dinikmati, agar supaya mereka mengucap syukur kepada$\mathrm{Mu}$; namun bagi kami Engkau telah menganugerahkan makanan rohani dan minuman rohani dan kehidupan abadi, melalui Yesus Kristus hamba-Mu.

4. Untuk semuanya itu kami mengucap syukur kepada-Mu, karena Engkau berkuasa. Kemuliaan bagi-Mu sepanjang segala masa (...).

Ucapan syukur yang kedua dimulai dengan pernyataan tentang Allah sebagai pencipta yang menciptakan segala sesuatu (10:3). Motif dari ucapan syukur adalah Tuhan sebagai penguasa dan pencipta segala sesuatu. Karya ciptaan Tuhan nyata melalui berkat makanan dan minuman rohani. Makanan dan minuman jasmani yang dianugerahkan Tuhan kepada manusia dibedakan dari makanan dan minuman rohani. Tuhan menganugerahkan makanan dan minuman rohani kepada orang-orang Kristen melalui Yesus Kristus. Di dalam perjamuan ekaristi, umat Kristen mengungkapkan syukur atas karya ciptaan dan atas rahmat makanan yang dianugerahkan Tuhan melalui Yesus Kristus. Roti dan anggur merupakan simbol dari makanan dan minuman duniawi. Namun kedua elemen ini diakui sebagai pemberian dari Sang Pencipta. Roti dan anggur dipersembahkan dalam perjamuan ekaristi mengingatkan umat Kristen akan rahmat ciptaan Allah dalam kehidupan manusia. Rahmat ciptaan inilah yang menjadi alasan bagi umat untuk mengucap syukur dalam perjamuan ekaristi.

Dua contoh teks doa di atas menunjukkan kepada kita bahwa pujian dan syukur atas Allah Sang Pencipta dan atas karya ciptaan-Nya merupakan elemen yang tak terpisahkan dalam perjamuan makan atau perjamuan ekaristi. Tidak ada doa pujian dan ucapan syukur tanpa menyinggung Sang Pencipta dan karya-Nya. Birkat ha-mazon dan Doa Syukur dalam Didache memainkan peranan yang sangat penting bagi pembentukan DSA kuno. Pujian dan syukur kepada Pencipta atas karya ciptaan-Nya juga menjadi bagian esensial dari DSA Gereja sampai saat ini. Sejak awal, ketika merayakan ekaristi, umat Kristen sudah mengarahkan hati dan budinya pada keagungan Sang Pencipta dan keindahan karya ciptaan-Nya. Segenap ciptaan dibawa dan diikutsertakan di dalam perayaan liturgi. 


\section{Motif Penciptaan dalam Anafora Klasik}

Struktur dasar dari birkat ha-mazon dan Doa Syukur dalam Didache memberikan pengaruh yang sangat penting bagi pembentukan awal DSA atau anafora liturgi Kristen awal. Pujian - Syukur - Permohonan membentuk elemenelemen dasar dari anafora-anafora klasik. Konsekuensinya, motif penciptaan atau pujian syukur atas Allah pencipta dan karya ciptaan-Nya menjadi bagian yang tak terpisahkan dari anafora awal. Tidak ada ekaristi tanpa pujian dan syukur kepada Allah Pencipta dan segala karya ciptaan-Nya. Dimensi ini sangat jelas dalam bagian anafora yang disebut oratio theologica dan oratio oeconomica. Oratio theologica adalah bagian pertama dari anafora yang berisikan pemuliaan nama Tuhan dan eksistensi Tuhan sebagai pencipta. Sedangkan, oratio eoconomica menunjuk pada bagian kedua anafora yang berisikan pujian syukur kepada Tuhan atas karya penciptaan dan keselamatan-Nya bagi umat manusia.

Pada bagian ini penulis hendak membuat sebuah analisa atas teks oratio theologica dan oratio oeconomica dari anafora klasik. Penulis hanya membatasi diri pada dua anafora penting yang sampai sekarang masih digunakan di dalam liturgi Gereja Kristen Timur, yakni anafora Yakobus versi Yunani dan anafora St. Basilius versi Alexandria (Mesir). Uraian ini bermaksud untuk menunjukkan bahwa pujian syukur kepada Tuhan sebagai pencipta dan atas segala karya ciptaan-Nya merupakan bagian yang tak terpisahkan dari doa ekaristi atau anafora.

\section{Anafora St. Basilius versi Alexandria (Mesir)}

Anafora St. Basilius memiliki tiga versi, yakni versi Alexandria (Mesir), Suriah dan Bizantin. Versi Alexandria adalah yang terpendek, tetapi sekaligus yang tertua. Sampai sekarang ini, anafora St. Basilius versi pendek ini tetap digunakan sebagai anafora standar di dalam liturgi Gereja Koptik di Mesir. Karakteristik dari anafora ini adalah penggunaan kutipan dan singgungan biblis yang sangat kaya. Menurut Bouyer, St. Basilius adalah pencipta pertama dari doa ekaristi yang berusaha untuk menggunakan rumusan-rumusan Kitab Suci bahkan secara harafiah. ${ }^{13}$ Kedekatannya dengan teks Kitab Suci dan daya sintesis dari gagasan-gagasannya membuat anafora ini dipandang sebagai sa-

${ }^{13}$ Bdk. Louis Bouyer, The Eucharist. Theology and Spirituality of the Eucharistic Prayer (Notre Dame: University of Notre Dame Press, 1968), hal. 291. 
lah satu dari kumpulan-kumpulan doa ekaristi yang terindah dalam tradisi liturgi.

Dalam konteks reformasi DSA sesudah Konsili Vatikan II, anafora St. Basilius ini sangat penting. Terjemahan latin dari anafora ini pernah menjadi salah satu usulan rancangan DSA untuk buku misa. Sayangnya, diskusi tentang kemungkinan menerima teks anafora St. Basilius ke dalam liturgi Katolik Roma mengalami jalan buntu. Sebagai gantinya, disusunlah sebuah DSA baru, yakni DSA IV yang berorientasi pada teks anafora St. Basilius ini.

Salah satu dari elemen-elemen dasar anafora ini adalah pujian syukur kepada Tuhan sebagai pencipta. ${ }^{14}$ Elemen penting ini diuraikan mulai dari sapaan kepada Allah pada bagian awal anafora sampai dengan bagian Sanctus (Kudus). Gagasan penciptaan tampak jelas dalam proklamasi anamnetis dari seluruh sejarah keselamatan.

Ayat pertama (oratio theologica) berisikan pujian kepada Tuhan Pencipta. Teksnya adalah sebagai berikut: ${ }^{15}$

(Pemimpin): Ya Tuhan, Sang Ada, Penguasa, Allah Kebenaran, Engkau ada sebelum segala waktu dan berkuasa sampai pada kekekalan, Engkau yang berdiam di tempat yang maha tinggi selama-lamanya dan memandang yang rendah, Engkau telah menciptakan surga dan bumi dan laut dan segala sesuatu yang ada di dalamnya. Bapa dari Allah dan Tuhan dan penyelamat kami Yesus Kristus, melalui Dia Engkau telah menciptakan segala sesuatu, yang kelihatan dan yang tidak kelihatan. Engkau yang duduk di atas takhta kemuliaan yang kudus dari kerajaan-Mu, Engkau yang disembah oleh setiap kekuatan yang kudus.

(Diakon): Yang duduk, berdirilah!

Berdiri di hadapan malaikat dan malaikat Agung, berdirilah segenap kekuasaan dan kekuatan, takhta, kerajaan dan kekuatan (Diakon: Menghadap ke timur), dalam lingkaran berkelilinglah kerubim yang bermata banyak dan Sefarim yang memiliki enam sayap, dengan tak henti-hentinya memuji, bersorak dan berseru: Kudus.

${ }^{14}$ Bdk. Achim Budde, Die ägyptische Basilios-Anaphora. Text, Kommentar, Geschichte (Münster: Aschendorff, 2004), hal. 240.

${ }^{15}$ Bdk. Diterjemahkan dari teks versi bahasa Jerman, dalam Meßner, Einführung, hal. 240. Teks Yunani dan Latin dapat dilihat dalam Prex Eucharistica, Textus a variis liturgiis antiquiribus selecti, diedit oleh Anton Hänggi - Irmgard Pahl (Fribourg: Universitätsverlag, 1968), hal. 348349. 
Ayat kedua (oratio oeconomica) berisikan proklamasi anamnetis tentang seluruh sejarah keselamatan. Kutipan teks berikut ini hanya menyinggung tentang motif penciptaan: ${ }^{16}$

Kudus, Kudus, sungguh kuduslah Engkau, Tuhan Allah kami. Engkau yang telah membentuk kami dan menempatkan kami ke dalam firdaus kesenangan.

Oratio Theologica dari Anafora St. Basilius ini berisikan pemuliaan nama Tuhan dan pujian kepada Allah pencipta melalui seluruh ciptaan. Teks doa ini memberikan kesaksian bahwa Allah Pencipta alam semesta dipuji dan dimuliakan baik oleh makhluk duniawi maupun surgawi atas dasar keberadaanNya dan terutama karena karya penciptaan-Nya. Di dalamnya umat yang berdoa memainkan peranan yang sangat penting. Mereka mengungkapkan pujian atas penciptaan secara ritual dan dengan demikian menghantar seluruh ciptaan dalam relasi yang khas dengan Allah Penciptanya. Gagasan ini membentuk elemen dasar dari doa ekaristi, yakni pengudusan dan pemuliaan nama Tuhan dan pujian kepada Tuhan Sang Pencipta melalui seluruh ciptaan. ${ }^{17}$ Sehubungan dengan itu, teks anafora berbicara tentang keberadaan dasar pencipta di hadapan Sang Pencipta, yakni jarak dan relasi. ${ }^{18}$ Di dalam sapaan kepada Allah sebagai Yang Berada, jarak antara Pencipta dan ciptaan ini terungkap secara jelas. Allah pencipta berada di dalam kekekalan dan transendensi-Nya yang tak dapat dihampiri oleh semua ciptaan yang lain.

Gerakan ke bawah dari Allah (dari atas ke bawah) membuka sebuah relasi yang baru dengan ciptaan-Nya. Allah yang berada di atas memandang semua yang rendah atau segenap ciptaan-Nya yang berada di bawah. Dengan menciptakan surga dan bumi Allah masuk ke dalam relasi yang khusus dengan ciptaan-Nya. Dan di dalam aklamasi Sanctus semua makhluk masuk dalam relasi satu sama lain dan terutama relasi dengan Sang Pencipta.

Dengan demikian gagasan di atas membentuk sebuah peralihan dari realitas jarak ke relasi. Di satu pihak, surga dan bumi, dunia yang kelihatan dan yang tidak kelihatan, manusia dan para malaikat, bersatu dalam pujian kepada Tuhan. Di lain pihak, terjadilah sebuah keterikatan yang khusus antara pencipta

\footnotetext{
16 Bdk. Meßner, Einführung, hal. 390.

17 Bdk. Ibid., hal. 202.

18 Bdk. Budde, Die ägyptische Basilios-Anaphora, hal. 265.
} 
dan segala ciptaan dalam perkumpulan liturgis. Di dalamnya, pujian atas ciptaan memainkan peranan yang sangat penting. Anafora St. Basilius ini menampilkan kepada kita sebuah bentuk liturgi kosmis di mana pujian surgawi dan duniawi atas Allah Pencipta bersatu.

Pujian syukur dari ciptaan surgawi dan duniawi harus menjadi tujuan dari seluruh doa ekaristi. Inilah tujuan dari Gereja yang berdoa, yakni memasukkan dunia yang kelihatan ke dalam pujian syukur kepada Allah Pencipta dan ke dalam kebersamaan dengan Pencipta dan kebersamaan satu sama lain.

Anafora ini memperjelas bahwa Allah mewahyukan diri di dalam sejarah manusia yang dimulai dengan sejarah penciptaan alam semesta dan manusia, dan berlanjut pada karya penyelamatan. Sebagaimana anafora klasik lainnya, anafora St. Basilius menggunakan gagasan yang diambil dari Kej 2:7-17. Karya penciptaan Allah yang dipadatkan pada penciptaan manusia pertama bermuara dalam anugerah Firdaus sebagai ruang kehidupan bagi manusia: "Engkau telah membentuk kami dan menempatkan kami ke dalam firdaus kesenangan".

\section{Anafora St. Yakobus versi Yunani}

Anafora St. Yakobus termasuk dalam liturgi Suriah Barat yang berpusat di Yerusalem dan digunakan oleh jemaat Kristen di Yerusalem. ${ }^{19}$ Kemungkinan anafora ini disusun sekitar akhir abad ke-4 atau awal abad ke-5. Anafora ini memainkan peranan yang sangat penting untuk mengerti perkembangan literer dari anafora pada abad ke-4 dan ke-5 dan juga bagi penelitian makna teologis dari doa ekaristi. Bouyer menyebut anafora ini sebagai monumen literer yang paling lengkap dari keseluruhan literatur liturgis. ${ }^{20}$ Dalam konteks tulisan ini, anafora ini sangat penting. Anafora St. Yakobus versi Yunani memberikan kesaksian

tentang sebuah rumusan doa ekaristi di mana relasi antara Pencipta dan ciptaan terjadi melalui pujian syukur kepada Allah pencipta.

Berikut ini adalah teks oratio theologica. Di dalamnya terungkap secara jelas bahwa dunia yang kelihatan dan tak kelihatan, Gereja surgawi, makhluk surgawi dan para malaikat dipanggil untuk memuji dan memuliakan Tuhan Pencipta: ${ }^{21}$

\footnotetext{
${ }^{19}$ Bdk. John D. Witvliet, “The Anaphora of St. James”, dalam Essay on Early Eastern Eucharistic Prayers, ed. Paul P. Bradshaw (Collegeville: Liturgical Press, 1997), hal. 153.

${ }^{20}$ Bdk. Bouyer, The Eucharist, hal. 268.

${ }^{21}$ Bdk. Teks di atas diterjemahkan dari Griechische Liturgien, Übersetzt von Remigius Storf(Kempten, 1912), hal. 104. Teks Yunani dan latin terdapat dalam Prex Eucharistica, hal. 244-247.
} 
Sungguh layak dan benar, pantas dan berguna untuk memuji-Mu, memadahkan-Mu, meluhurkan-Mu, menyembah-Mu, memuliakan-Mu dan bersyukur kepada-Mu, Pencipta dunia yang kelihatan dan yang tak kelihatan, Harta kebaikan-kebaikan yang kekal, Sumber Kehidupan dan Kekekalan, Allah dan Penguasa alam semesta. Surga dari surga dan semua kekuatannya, matahari, bulan dan segenap paduan suara bintang-bintang, bumi, laut dan semua yang ada di dalamnya memuji-Mu. Perkumpulan surgawi di Yerusalem, Gereja dari Anak Sulung yang tercatat di surga, roh-roh dari orang-orang benar dan para nabi, jiwa-jiwa para martir dan para rasul, para malaikat, malaikat Agung, takhta, kekuasaan, penguasa, kuasa dan kekuatan, Kerubim bermata banyak dan Sefarim bersayap enam, semuanya memujiMu. Dengan dua sayapnya mereka menutupi wajah mereka dan dengan dua sayapnya mereka menutupi kaki mereka dan mereka berseru bersahutsahutan dengan suara yang tak henti-hentinya dan dengan teologi ( $\alpha \sigma \gamma \eta \dot{\tau} \tau o r \varsigma$ $\theta \varepsilon 0 \lambda$ oríaı) yang tak pernah diam.

Sedangkan, teks oratio oeconomica berbunyi sebagai berikut: ${ }^{22}$

Kuduslah Engkau, Raja dari kekekalan dan Tuhan dan Pemberi setiap kesucian; kuduslah juga Putera Tunggal-Mu, Tuhan kami Yesus Kristus, melalui Dia Engkau telah menciptakan segala sesuatu; kuduslah juga Roh Kudus-Mu, yang mendasarkan semua, kedalaman dari keallahan. Kuduslah Engkau Allah yang maha kuasa, Yang Tak terbatas, Yang Baik, Yang Menggentarkan, Yang Murah Hari dan penuh belas kasih terutama bagi citra-Nya. Engkau telah menciptakan manusia dari bumi menurut citra-Mu dan keserupaan dengan-Mu, Engkau telah menganugerahkan kepadanya kenikmatan firdaus. Dan sesudah manusia tidak mematuhi perintah-Mu dan dia diusir dari firdaus, Engkau, Tuhan yang baik, tidak meninggalkan dan mengabaikannya, melainkan sebagai Bapa yang berbelas kasih Engkau telah mendidiknya, memanggilnya melalui hukum dan membentuknya melalui para nabi.

Ada dua gagasan dasar yang mewarnai oratio theologica. Yang pertama adalah pengakuan akan eksistensi Allah sebagai pencipta dan penguasa segala sesuatu. Allah yang bertakhta di surga diakui sebagai pencipta segala sesuatu yang kelihatan maupun yang tidak kelihatan. Yang kedua adalah pujian kepada

${ }^{22}$ Bdk. Griechische Liturgien, hal. 104-105. Teks Yunani dan Latin dapat dilihat dalam Prex Eucharistica, hal. 247. 
Allah Pencipta karena karya ciptaan-Nya. Atas dasar karya penciptaan-Nya Allah dipuji oleh surga dan surga dari surga dan semua kekuatannya, oleh matahari bulan dan seluruh panduan suara bintang-bintang, laut dan semua yang ada di dalamnya. Dalam anafora ini tema tentang Yerusalem surgawi mendapatkan tempat khusus. Yerusalem surgawi merupakan tempat di mana seluruh ciptaan, baik yang kelihatan maupun yang tidak kelihatan, yang di dunia maupun yang di langit, bertemu. Seruan Kudus (Sanctus) menggambarkan sebuah liturgi surgawi di mana seluruh ciptaan dan makhluk surgawi bersekutu satu sama lain di dalam pujian kepada Tuhan Pencipta.

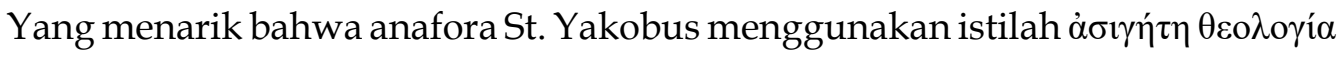

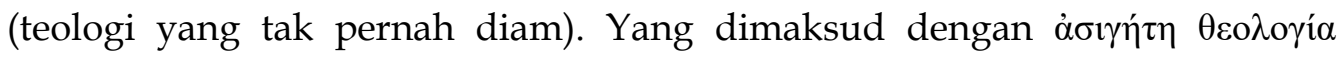
(teologi yang tak pernah diam) bukanlah teologi sebagai sebuah refleksi kritis atas iman, melainkan teologi dalam arti doksologi atau glorificatio Dei (pujian kepada Tuhan).

Bagian kedua (oratio oeconomica) berisikan pujian anamnetis sejarah keselamatan-Nya, yang dimulai dari penciptaan, kejatuhan manusia, hukum dan para nabi, dan inkarnasi yang berpuncak pada pemenuhan eskatologis. Sehubungan dengan motif, anafora St. Yakobus menyinggung interpretasi biblis tentang manusia sebagai citra Allah: Engkau yang telah menciptakan

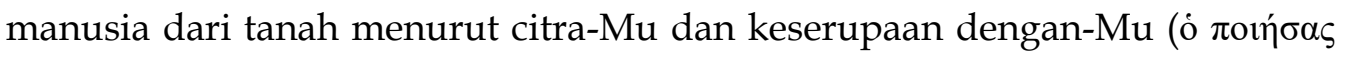

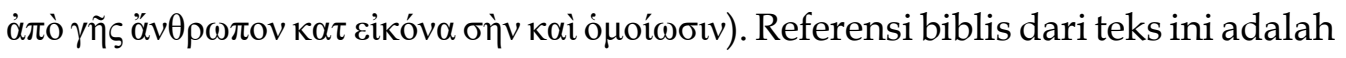
Kej 1:26-27. Menurut Walter Groß, teks Kitab Kejadian ini berbicara tentang tatanan ruang kehidupan dan koeksistensi yang damai dari semua ciptaan. ${ }^{23}$ Allah menyelesaikan tata ciptaan dan membuatnya sangat baik terutama dengan menciptakan manusia menurut citra-Nya. Ia mengangkat manusia sebagai wakil Allah dan memberikan kepadanya kekuasaan yang bertanggung jawab dan damai atas seluruh ciptaan. Groß menambahkan bahwa manusia adalah citra Allah sejauh ia bertindak secara bertanggung jawab terhadap ruang kehidupan dan terhadap segala makhluk hidup di dalamnya, dan bukan sejauh ia bertindak sewenang-wenang, seolah-olah ia seperti Allah. ${ }^{24}$ Dengan demikian manusia merealisasikan keistimewaannya sebagai citra Allah melalui tugas sebagai penguasa alam semesta. Kepada manusia diberikan tugas agar ia berkuasa atas ikan-ikan di laut dan burung-burung di udara, dan atas segala se-

${ }^{23}$ Bdk. Walter Groß, "Die Gottebenbildlichkeit des Menschen im Kontext der Priesterschrift", Theologische Quartalschrift 161 (1981), hal. 261.

${ }^{24}$ Bdk. Ibid., hal. 261. 
suatu yang ada di bumi ini. Namun tugas itu tidak boleh dimengerti sebagai sebuah kekuasaan absolut, melainkan sebagai sebuah pelayanan. Manusia menjalankan pelayanan tersebut dalam ketaatan dan ketergantungan total kepada Tuhan pencipta. Di sinilah terletak sebenarnya martabat manusia sebagai citra Allah.

Gagasan ini hendak menggarisbawahi tugas penguasaan yang bertanggung jawab dan damai yang dipercayakan kepada manusia. Manusia adalah raja atau penguasa atas ciptaan. Status ini sebenarnya mengimplikasikan sebuah tanggung jawab untuk memelihara dan menjaga seluruh rekan tercipta terhadap segala sesuatu yang sifatnya merusak dan menghancurkan. Tugas mulia ini disalahgunakan oleh manusia ketika ia tidak taat pada perintah Tuhan. Kejatuhannya ke dalam dosa berakibat bahwa manusia kehilangan martabat luhurnya sebagai citra Allah dan tanggung jawabnya sebagai penjaga dan pemelihara alam semesta. Namun Allah pencipta tidak menghendaki kehancuran ciptaan. Oleh karena itu Allah berusaha untuk menyelamatkan kembali manusia yang sudah jatuh dalam dosa dan membaharui kembali tatanan penciptaan yang hancur karena kejatuhan manusia. Untuk rencana penyelamatan itu, Allah mengutus para nabi dan memberikan hukum kepada bangsa Israel, dan yang terakhir, Allah mengutus Putera-Nya sendiri ke dalam dunia. Kristus sebagai pengantara ciptaan dan Pencipta, ia telah membaharui kembali martabat manusia sebagai citra Allah yang hilang karena ketidaktaatan.

\section{Doa Syukur Agung dalam Missale Romanum 1970}

Uraian di atas sudah menunjukkan kepada kita bahwa syukur atas karya penciptaan Allah merupakan elemen yang tak terpisahkan dari anafora atau DSA. Jika dalam konteks reformasi DSA sesudah Konsili Vatikan II tema ini mendapatkan tempat dalam teks DSA yang baru, maka fakta ini dapat dipandang sebuah inovasi yang berakar dari tradisi. Pada bagian ini fokus perhatian diarahkan pada motif penciptaan dalam DSA baru dalam Buku Misa Romawi 1970, yakni DSA II, III, IV. Pembatasan ini semata-mata demi alasan metodologis, tanpa bermaksud untuk mengabaikan DSA lain yang ada dalam Missale Romanum Editio Typica Tertia (2002). ${ }^{25}$

${ }^{25}$ Syukur atas karya ciptaan Allah diungkapkan juga dalam prefasi DSA VIII - Prex eucharistica pro Missis cum pueris I (TPE, hal. 185-186), Prefasi DSA IX - Prex eucharistica pro Missis cum pueris II (TPE, hal. 194). Motif yang sama juga terdapat dalam Prefasi V Hari Minggu Biasa dengan tema Penciptaan (TPE, hal. 72). 
Motif Penciptaan dan Reformasi Doa Syukur Agung

Sejak Missale Romanum 1570 sampai edisi terakhirnya dalam Missale Romanun 1962, ekaristi hanya mengenal satu DSA, yakni Canon Romanus atau DSA I. Canon Romanus memiliki struktur yang sangat berbeda dengan anafora-anafora yang sudah diuraikan sebelumnya. Dua elemen dasar dari anafora klasik, yakni oratio theologica dan oratio oeconomica, tidak terdapat di dalam Canon Romanus. Canon ini lebih banyak berisikan doa-doa permohonan dengan kisah institusi sebagai pusat keseluruhan DSA. Konsekuensinya, pujian syukur kepada Tuhan sebagai pencipta dan bagi seluruh karya ciptaan-Nya tidak mendapat tempat di dalam Canon Romanus. Tema tentang kurban ekaristi menjadi kekhasan dari Canon Romanus.

Salah satu buah dari pemugaran liturgi sesudah Konsili Vatikan II adalah pembaharuan ordo missae atau tata perayaan ekaristi. Pembaharuan ini mau tidak mau menyentuh juga Canon Romanus yang selama berabad-abad tak berubah. Awalnya, antusiasme pembaharuan hanya terbatas pada sekedar merevisi teks Canon Romanus. Namun, orang menyadari bahwa Canon ini memiliki nilai historis, teologis dan spiritual yang mendalam. Rasa enggan mulai muncul untuk memodifikasi sebuah teks klasik yang sudah mendampingi perjalanan liturgi Gereja selama berabad-abad. Oleh karena itu, sebagai alternatifnya muncul usaha untuk menciptakan Doa Syukur Agung yang baru, entah DSA yang disusun benar-benar baru (nova compositio) atau yang diadaptasi dari DSA yang sudah ada dalam tradisi liturgi. Hasil dari reformasi DSA termuat dalam Missale Romanum 1970, yakni DSA I (Canon Romanus yang direvisi secara sangat minimal), DSA II, DSA III, DSA III). Dalam konteks pembahasan ini, hal yang terpenting adalah tema penciptaan dimasukkan ke dalam DSA-DSA yang baru tersebut (DSA II, III, IV).

\section{Doa Syukur Agung II}

DSA II merupakan hasil adaptasi dari DSA Tradisi Apostolis (sering kali disebut DSA Hippolitus dari Roma). Dalam DSA Tradisi Apostolis, kenangan akan sejarah keselamatan, yakni karya penciptaan dan karya penebusan Kristus melalui sengsara dan kebangkitan-Nya, diuraikan secara jelas. ${ }^{26}$ Elemen-elemen

${ }^{26}$ DSA Tradisi Apostolis berbunyi: “Gratias tibi referimus, Deus, per dilectum puerum tuum Iesu Christum, (quem in ultimis temporibus misisti nobis salvatorem et redemptorem et angelum voluntatis tuae, qui est) Verbum tuum inseparabile, per quem omnia fecisti". Lihat Prex Eucharistica, hal. 81. 
ini membentuk prefasi dari DSA II yang berisikan anamnesis karya penciptaan dan karya penyelamatan Kristus. Berikut ini adalah kutipan teks prefasi DSA II di mana motif penciptaan diungkapkan secara jelas:

Sungguh layak dan sepantasnya, ya Bapa yang kudus, Allah yang kekal dan kuasa, kami senantiasa bersyukur kepada-Mu dengan pengantaraan Yesus Kristus, Putra-Mu yang terkasih. Dialah Sabda-Mu. Dengan Sabda-Mu itu, Engkau menciptakan alam semesta (TPE 125).

Teks prefasi dari DSA II ini menunjukkan bahwa Kristus menjadi pengantara bagi manusia untuk mengucap syukur kepada Tuhan. Dalam peran itu, Kristus diperkenalkan sebagai Putra yang terkasih dan Sabda(logos). Karya penciptaan dari Sang Sabda ini ditekankan. Allah menciptakan segala sesuatu melalui Kristus sebagai Sabda Allah yang telah menjadi manusia. DSA II menampilkan sebuah gagasan ciptaan yang bernuansa kristologis. Kristus adalah pengantara semua ciptaan. Di sini teks DSA II menghantar kita pada motif klasik DSA, yakni dimensi kosmis dari karya penyelamatan Kristus. Kristus adalah juru selamat bukan hanya bagi manusia tetapi juga bagi seluruh ciptaan. Di dalam Kristus kesatuan antara karya penyelamatan dan karya penciptaan menjadi jelas: Quem misisti nobis salvatorem et redemptorem.

\section{Doa Syukur Agung III}

DSA III berorientasi pada Canon Romanus. Namun, teks dasar dari DSA ini berasal dari Cipriano Vagaggini. Dalam rangka proyek reformasi DSA, Vagaggini membuat sebuah studi perbandingan teks-teks DSA dalam tradisi liturgi. Hasil studinya ini dipublikasi dalam bukunya Il canone della messa e la riforma liturgica. ${ }^{27}$ Dalam proyeknya ini, Vagaggini menawarkan dua rancangan DSA atau Kanon, yakni Kanon B ${ }^{28}$ dan Kanon $C^{29}$. Teks Kanon B menjadi bahan dasar untuk DSA III, sedangkan teks Kanon C menjadi cikal bakal DSA IV.

Gagasan tentang penciptaan muncul secara singkat dalam teks doa sesudah Sanctus (Kudus).

\footnotetext{
${ }^{27}$ Cipriano Vagaggini, Il canone della messa e la riforma liturgica. Problemi e progetti. Torino-Leumann 1966 (QRivLi 4). Edisi bahasa Inggris: Cipriano Vagaggini, The Canon of the Mass and Liturgical Reform (London: Alba House,1967), hal. 124-129.

${ }^{28}$ Teks dari Kanon B dapat dilihat dalam Vagaggini, The Canon of the Mass, hal. 124-129.

${ }^{29}$ Teks dari Kanon C dapat dilihat dalam Vagaggini, The Canon of the Mass, hal. 130-138.
} 
Sungguh kuduslah Engkau, ya Bapa. Segala ciptaan patut memuji Engkau. Sebab, dengan pengantaraan Putra-Mu, Tuhan kami Yesus Kristus, dan dengan daya kekuatan Roh Kudus, Engkau menghidupkan segala sesuatu (TPE, hlm. 135).

Hal yang mencolok dalam teks di atas adalah bahwa kenangan akan karya penciptaan memiliki dimensi trinitaris. ${ }^{30}$ Pertama-tama, teks DSA III menampilkan sebuah nuansa liturgi kosmis, yakni pujian dari sebuah ciptaan (omnis a te condita creatura). Kesadaran identitas seluruh ciptaan diperkuat melalui pujian bersama kepada Sang Pencipta. Teks doa juga mengangkat peranan Kristus sebagai pengantara penciptaan. Melalui Kristus Allah menganugerahkan segala yang baik kepada dunia. Kemudian teks menunjuk pada daya kekuatan Roh Kudus yang bekerja juga di dalam penciptaan.

\section{Doa Syukur Agung IV}

Teks DSA IV adalah satu-satunya DSA yang secara sangat konsisten berakar pada anafora Liturgi Ritus Timur, khususnya anafora St. Basilius versi Alexandria (Mesir). Rancangan teks dari Cipriano Vagaggini (Kanon C) sebenarnya menjadi dasar bagi keseluruhan struktur dan gagasan teologis DSA IV. Vagaggini menyusun sebuah rancangan teks Kanon (DSA) yang berorientasi secara khusus pada anafora St. Basilius versi Alexandria. ${ }^{31}$ Gagasan dasar di balik proyek ini adalah menyusun sebuah teks DSA yang menampilkan sebuah uraian yang menyeluruh tentang sejarah keselamatan, mulai dari penciptaan sampai dengan harapan eskatologis. Salah satu aspek teologis yang Vagaggini hendak tekankan di dalam proyek Kanonnya adalah penciptaan. ${ }^{32}$ Gagasan dasar dari Vagaggini memberikan pengaruh yang sangat besar bagi penyusunan DSA IV, terutama motif penciptaan. Hal ini bersesuaian dengan salah satu maksud penyusunan DSA IV, yakni sebuah DSA yang mampu mengungkapkan juga pergumulan konkret manusia sekarang ini dengan bahasa yang bisa dimengerti oleh manusia modern. Problem keutuhan ciptaan adalah salah satu pergumulan manusia modern.

Sebagaimana dalam anafora St. Basilius, oratio theologica dan oratio oeconomica mendapat tempat dalam teks DSA IV. Bagian oratio theologica (dalam buku litur-

\footnotetext{
${ }^{30}$ Bdk. Enrico Mazza, The Eucharistic Prayers of the Roman Rite (Collegeville: Liturgical Press, 1984), hal. 126.

${ }^{31}$ Bdk. Vagaggini, The Canon of the Mass, hal. 139.

${ }^{32}$ Bdk. Ibid, hal. 146.
} 
gi disebut prefasi) berisikan pemuliaan eksistensi Tuhan pada diri-Nya sendiri dan pujian syukur kepada Tuhan sebagai pencipta.

Sungguh layak dan sepantasnya, ya Bapa yang kudus, kami bersyukur dan memuliakan Dikau. Sebab Engkaulah satu-satunya Allah yang hidup dan benar. Sebelum awal zaman Engkau sudah ada dan akan tetap ada selamalamanya; Engkau bersemayam dalam cahaya yang tak terhampiri. Hanya Engkaulah yang baik, sumber kehidupan, Pencipta segala sesuatu. Engkau melimpahkan berkat-Mu dan membahagiakan segala makhluk dengan terang cahaya-Mu. Di hadirat-Mu para malaikat yang tak terbilang jumlahnya siang malam berbakti kepada-Mu, dan sambil memandang wajah-Mu yang mulia tak henti-hentinya memuliakan Dikau. Bersama mereka, dan atas nama segala ciptaan di bawah langit, kami pun melambungkan pujian bagi nama$\mathrm{Mu}$, dan dengan bersukacita berseru (TPE 143-144).

Motif dari syukur dan pemuliaan Tuhan adalah di satu pihak karena transendensi dan keabadian-Nya, dan di lain pihak karena imanensi-Nya: Allah adalah Pencipta yang dekat dengan ciptaan-Nya. Teks DSA menggambarkan Allah sebagai asal usul segala ciptaan. ${ }^{33}$ Sekaligus juga, tujuan karya penciptaan diungkapkan secara jelas, yakni bahwa Allah ingin memenuhi seluruh ciptaanNya dengan berkat dan menganugerahkan semua dengan kegembiraan dalam terang cahaya-Nya.

Yang menarik bahwa teks pengantar ke Sanctus menampilkan sebuah permenungan yang mendalam tentang relasi manusia dengan segenap ciptaan lainnya. Ini adalah gambaran tentang liturgi kosmis. Bersama dengan segenap penghuni surgawi, umat Gereja hadir sebagai imam bagi seluruh ciptaan. ${ }^{34}$ Dalam perayaan ekaristi Gereja bertindak sebagai pengantara seluruh ciptaan lain yang ada di bawah bumi untuk menyampaikan pujian kepada Sang Pencipta. Gereja adalah suara pujian dari segenap makhluk tercinta yang tanpa suara (voice of the voiceless). Sanctus (Kudus) juga mengungkapkan dimensi kosmis dari ekaristi. ${ }^{35}$ Dipenuhi dengan kemuliaan Allah, segenap ciptaan Allah yang merayakan liturgi di dunia bersatu padu dengan pujian para malaikat yang merayakan liturgi surgawi. Di dalam Sanctus bersatulah liturgi surgawi

\footnotetext{
${ }^{33}$ Bdk. Keenan, "The Importance”, hal. 344-345.

${ }^{34}$ Bdk. Mazza, The Eucharistic Prayers, hal. 162.

${ }^{35}$ Bdk. Keenan, "The Importance", hal. 349.
} 
dan liturgi duniawi.

Teks oratio oeconomica (Post Sanctum) berisikan proklamasi anamnesis atas seluruh sejarah keselamatan Allah yang terdiri dari penciptaan dunia dan manusia, penyelamatan manusia (Israel) melalui Hukum dan Para Nabi, karya penebusan Yesus Kristus yang berpuncak pada misteri Paskah (sengsara, wafat dan kebangkitan) dan karya pengudusan melalui Roh Kudus. Berikut ini adalah kutipan teks oratio oeconomica yang berbicara tentang pujian atas karya penciptaan Allah:

Kami memuji Engkau, ya Bapa yang kudus, sebab agunglah Engkau, dan segala karya-Mu Engkau laksanakan dengan penuh kebijaksanaan serta kasih sayang. Engkau menciptakan manusia seturut citra-Mu dan menyerahkan kepadanya tugas untuk memelihara alam semesta, supaya ia berkuasa atas segala ciptaan dan berbakti kepada-Mu, Pencipta alam semesta (TPE 144).

Kutipan teks di atas secara khusus menegaskan kembali dimensi rohani dari eksistensi manusia dan makna hidupnya sebagai ciptaan Allah. Manusia diciptakan menurut citra Allah, dan manusia memikul tanggung jawab untuk melayani Pencipta dan sesama ciptaan Allah. ${ }^{36}$ Eksistensi manusia ditemukan bukan pertama-tama dalam akal budinya (animale rationale), bukan juga semata-mata dalam relasi sosialnya (zoon politikon), namun dalam relasinya dengan Tuhan. Sebab, Tuhan mengungkapkan kesempurnaan kebijaksanaan dan kasih-Nya dengan menciptakan manusia. Makna dari eksistensi manusia juga terungkap dalam relasinya dengan sesama ciptaan. Gagasan biblis, bahwa manusia diciptakan menurut citra Allah (bdk. Kej 1:26), menyingkapkan tanggung jawab luhur manusia untuk memelihara alam semesta. Karena itu, kuasa yang diberikan kepada manusia (bdk. Kej 1:28) harus dimengerti dalam konteks tugas untuk memelihara alam semesta, dan bukan untuk memanipulasi. Karena manusia diberi tugas untuk melayani Tuhan sang pencipta, maka tugas penguasaannya atas segenap ciptaan harus dilaksanakan dalam ketergantungan total kepada Tuhan. Artinya bahwa peran manusia sebagai penguasa atas seluruh ciptaan sama sekali tidak bermaksud untuk memproklamasikan sebuah antroposentrisme, melainkan sebuah theosentrisme. Martabat tertinggi dari manusia terletak dalam pelayanan-Nya kepada Pencipta dan segenap ciptaan.

${ }^{36}$ Bdk. Ibid, hal. 340. 
Gagasan ini menyirapkan sebuah persahabatan yang akrab antara Pencipta dan ciptaan. Selama manusia berusaha untuk memelihara alam ciptaan secara bertanggung jawab dan melayani Sang Pencipta dengan setia, maka ia berada dalam relasi yang damai dan bersahabat dengan segenap alam ciptaan.

\section{Doa Syukur Agung "Indonesia Tercinta"}

Dalam uraian ini, istilah yang dipakai dalam teks resmi liturgi adalah ciptaan atau Pencipta. Siapa itu pencipta dan apa itu ciptaan? Mungkin bagi sebagian masyarakat tradisional, terminologi ini terasa asing dan terlalu spekulatif. Dalam konteks itu, penulis hendak menyinggung sebuah teks DSA pribumi Indonesia yang pernah ada, namun tidak mendapatkan pengesahan resmi dari Vatikan. ${ }^{37}$ Yang menarik bahwa di dalam teksnya syukur atas karya ciptaan Allah diungkapkan dengan kata-kata dan ungkapan yang konkret dan mudah dimengerti oleh masyarakat Indonesia. Itulah teks DSA "Indonesia Tercinta" yang disusun oleh para dosen dan mahasiswa Sekolah Tinggi Filsafat Seminari Pineleng pada tahun 1975 dalam rangka lomba cipta DSA.

Kemunculan DSA Indonesia Tercinta berkaitan dengan usaha Gereja Katolik Indonesia untuk menyusun sebuah DSA pribumi Indonesia. ${ }^{38}$ Pada November 1973 Konferensi Uskup Indonesia menugaskan PWI-Liturgi untuk membuat satu naskah DSA yang baru. DSA itu harus bersifat pribumi yang nantinya dapat dimintakan pengesahan dari Roma. Dalam rangka itu, pada tanggal 4 Februari dan 15 Agustus 1974, PWI-Liturgi mengadakan Lomba Cipta Doa Syukur Agung Pribumi ${ }^{39}$ Lomba ini menghasilkan 7 naskah DSA. PWI Liturgi

${ }^{37}$ Uraian lengkap tentang Doa Syukur Agung Indonesia Tercinta, lihat Artur Waibel, "Das Eucharistische Hochgebet in Indonesien. Episoden vom anderen Ende der Welt", dalam Gemeinschaft der Eucharistiefeier im ökumenischen Gespräch, ed. Stefan Böntert (Regensburg: Friedrich Pustet, 2015).

${ }^{38}$ Pada tanggal 27 April 1973 Kongregasi Ibadat menerbitkan surat edaran bagi pimpinan Konferensi Uskup dengan judul Eucharistiae Participationem. Surat edaran itu bertujuan untuk menghentikan peredaran naskah DSA yang diciptakan atas inisiatif pribadi. Ditegaskan dalam nomor 6 bahwa kita tetap berpegang pada empat DSA dalam buku Misa (DSA I, II, III, IV). Namun, nomor yang sama menyatakan: “Dengan senang hati Takhta Suci akan menguji permohonan dari Konferensi Uskup yang berkeinginan bahwa di dalam situasi-situasi tertentu mungkin sebuah DSA yang baru akan disusun dan dimasukkan ke dalam perayaan liturgi". Bdk. Anibale Bugnini, Die Liturgiereform 1948-1975. Zeugnis und Testament. Deutsche Ausgabe herausgegebene von Johannes Wagner unter Mitarbeit von Francois Raas (Freiburg: Herder, 1988), hal. 507-508.

${ }^{39}$ Bdk. "Doa Syukur Agung Pribumi”. Bahan Studi (Solo: PWI Liturgi, 1975), hal. 1. 
harus memilih satu dari tujuh naskah yang akan dimintakan pengesahan dari Roma. Kriteria penilaian adalah (1) DSA tersebut harus bersifat Indonesia, (2) sesuai dengan situasi, kebutuhan dan daya tangkap umat sederhana, (3) memenuhi syarat-syarat sebuah DSA dari sudut struktur liturgis dan isi teologis. ${ }^{40}$ Dalam konsultasi tentang "Doa Syukur Agung" yang diadakan pada awal tahun 1975, PWI Liturgi memilih naskah DSA dari Sekolah Tinggi Filsafat Seminari Pineleng. Naskah DSA itu dinamakan DSA "Indonesia Tercinta". ${ }^{41}$ Setelah melalui koreksi dan perbaikan, DSA Indonesia tercinta akan dimintakan pengesahan dari Kongregasi Ibadat.

DSA “Indonesia Tercinta” memiliki 2 prefasi (Prefasi A dan B) dan 6 rumusan doa-doa permohonan sebagai pilihan. Dalam konteks pembahasan kita, teks Prefasi A mengungkapkan secara jelas pujian dan syukur atas karya ciptaan yang konkret dialami oleh masyarakat Indonesia:

Prefasi A:

Sungguh layak dan pantas, ya Bapa, kami persembahkan syukur dan pujian kepada-Mu. Sebab Engkau memperkenankan kami hidup di bumi Indonesia, di tengah pulau-pulau dan lautan, di antara gunung-gunung dan datar subur, di tanah yang kaya akan sumber-sumber alam. Engkau membimbing kami menjadi satu bangsa yang merdeka dan bertanggung jawab, untuk mengolah sawah ladang, membangun kota dan desa dan menyiapkan hari depan yang lebih adil dan makmur, aman sentosa. Terutama kami bersyukur kepada-Mu, sebab Engkau telah menanam dalam hati kami iman dan cinta akan Yesus Kristus, Putera-Mu dan penyelamat kami. Maka bersama dengan seluruh isi surga, kami memuji dan memuliakan Dikau sambil berseru: Kudus, Kudus, Kudus. $^{42}$

Pada bagian permohonan-permohonan (sebelum Doksologi), teks DSA Indonesia Tercinta masih menyinggung ajakan untuk membangun alam ciptaan dan harapan akan langit dan bumi yang baru: "Semoga kami ikut membangun alam ciptaan-Mu, sambil menantikan langit dan bumi yang baru". ${ }^{43}$

\footnotetext{
${ }^{40}$ Bdk. Ibid.

${ }^{41}$ Bdk. "Doa Syukur Agung Indonesia Tercinta" (Surakarta: PWI Liturgi, 1976), hal.1.

${ }^{42}$ Bdk. "Doa Syukur Agung", hal. 2.

${ }^{43}$ Ibid., hal. 8.
} 
Pada tanggal 12 Agustus 1976 Konferensi Uskup Indonesia mengirimkan naskah DSA Indonesia Tercinta kepada Prefek Kongregasi Ibadat. Konferensi Uskup memohon agar DSA ini boleh dipakai pada peringatan HUT RI ke 32 pada tanggal 17 Agustus 1977. Namun, permohonan pengesahan DSA ini ditolak oleh Roma. Kongregasi Ibadat berpendapat bahwa tidaklah tepat untuk mengesahkan sebuah DSA yang akan digunakan dalam sebuah peristiwa atau perayaan bukan gerejawi. Pada tanggal 18 Maret 1977, untuk kedua kalinya Konferensi Uskup Indonesia mengajukan permohonan untuk pengesahan DSA ini. Namun, Kongregasi Ibadat tetap pada pendiriannya untuk tidak mengizinkan pengesahan DSA ini.

Biarpun DSA “Indonesia Tercinta" tidak mendapatkan pengesahan dari Kongregasi Ibadat, namun sebagian dari naskah DSA masih bisa kita jumpai di dalam TPE yang dipakai saat ini. Naskah Prefasi A dari DSA Indonesia tercinta (dengan sedikit modifikasi) dimasukkan dalam TPE sebagai Prefasi Tanah Air I (lih. TPE 104-105). Begitu juga dua rumusan untuk permohonan dalam DSA Indonesia Tercinta, yakni rumusan nomor 1 dan 4, dimasukkan dalam TPE sebagai sisipan DSA dalam perayaan Ekaristi untuk tanah air atau peringatan kenegaraan (lih. TPE 105).

\section{KESIMPULAN}

Berdasarkan analisa berbagai contoh teks Doa Syukur Agung di atas, penulis hendak mengangkat beberapa aspek penting dari spiritualitas ekaristis yang relevan bagi dunia sekarang. Pertama-tama adalah kesadaran akan tanggung jawab manusia terhadap ciptaan. Mengacu pada Denis Edwards, ketika Gereja berkumpul untuk merayakan Ekaristi, mereka membawa bumi dan segala ciptaan ke atas meja altar. ${ }^{44}$ Merayakan ekaristi berarti mengangkat seluruh ciptaan ke dalam martabat yang lebih tinggi, yakni sebagai anugerah Sang Pencipta. Anugerah itu bukan untuk memenuhi egoisme manusia, melainkan sebuah alasan untuk selalu bersyukur kepada Sang Pemberi. Ekaristi adalah sebuah anamnesis yang hidup akan karya penciptaan dan karya keselamatan. Tindakan penyelamatan Allah yang dibuat pada masa lampau, kini dihadirkan kembali melalui medium pujian dan syukur. Ekaristi dapat juga dipandang sebagai sakramen Kristus kosmis. Gereja disadarkan bahwa tindakan penyelamatan Kristus tidak hanya bagi manusia, tetapi juga bagi seluruh cip-

${ }^{44}$ Bdk. Denis Edwards, Ecology at the Heart of Faith. The Change of Heart that Leads to a New Way of Living on Earth (Maryknoll: Orbis Books, 2011), hal. 99. 
taan, sebab Dia adalah awal dari segala dan pengantara segala ciptaan dengan Pencipta. Dengan merayakan ekaristi dalam kesadaran ini, maka Gereja bisa menumbuhkan solidaritas bagi kurban krisis ekologis sekarang ini.

Aspek penting lain yang pantas diangkat di sini adalah bahwa liturgi menjadi tempat di mana pertobatan ekologis dikumandangkan. Searah dengan Edwards, pertobatan ekologis terarah pada perubahan hati yang memimpin kita pada sebuah cara hidup baru di dunia ini. ${ }^{45}$

Motif penciptaan dalam DSA mengungkapkan relasi hakiki antara manusia dengan ciptaan dan terutama tanggung jawab khusus manusia untuk menjawab keutuhan ciptaan Allah. Tanggung jawab ekologis ini secara teologis berdasar pada martabatnya sebagai citra Allah. Martabat ini mengimplikasikan sebuah panggilan manusia untuk menjadi raja atas ciptaan. Manusia menerima martabat sebagai citra Allah dan tugas untuk berkuasa atas rekan ciptaan lainnya. Tugas yang dipercayakan Allah ini memperjelas posisi khususnya dan relasinya dengan ciptaan lainnya. Manusia adalah wakil Allah di dunia ini. Oleh karena itu kuasa manusia atas ciptaan tidak boleh berorientasi pada kepentingan sendiri, melainkan terarah pada pemenuhan kehendak Allah bagi seluruh ciptaan. Sebagai raja dari segenap ciptaan, manusia memikul tanggung jawab untuk melayani Pencipta dalam ketaatan mutlak dan menciptakan koeksistensi yang damai dengan makhluk ciptaan lain.

Motif penciptaan dalam DSA juga menawarkan kepada manusia sebuah kesadaran akan etika ekologis berhadapan dengan kekerasan dan kehancuran lingkungan hidup. Kita semua memikul tanggung jawab untuk menciptakan dan menjaga sebuah tata dunia yang lebih baik. Manfred Probst menjelaskan lebih lanjut: ${ }^{46}$ Saat ini manusia masuk dalam sebuah fase yang sangat menentukan dalam relasinya dengan ciptaan. Di satu pihak, dengan media teknik alam ciptaan membuka dirinya secara baru bagi manusia. Di lain pihak, dengan media yang sama ciptaan berada dalam ancaman yang besar. Dalam situasi ini, pantaslah bahwa kita bersyukur kepada Tuhan di dalam pusat dari ibadat Kristen dan menyadari secara baru bahwa ciptaan adalah pemberian yang Tuhan telah percayakan kepada manusia untuk dijaga dan dirawat, dan bukan untuk dihancurkan.

Gereja dipanggil untuk menampakkan karya keselamatan dan maksud Allah bagi segala ciptaan. Tugas Gereja adalah mempromosikan dan menunjukkan

\footnotetext{
${ }^{45}$ Bdk. Ibid., hal. 2-3.

${ }^{46}$ Bdk. Probst, "Schöpfungsmotiv", hal. 142.
} 
aksi nyata penghargaan dan perlindungan lingkungan sebagai ciptaan Allah. Berhadapan dengan kekerasan terhadap alam Gereja memiliki kewajiban untuk mempromosikan budaya tanpa kekerasan dan penghormatan terhadap alam. Sebagai suara dari ciptaan yang tanpa suara, Gereja harus masuk ke dalam solidaritas yang sadar dengan alam yang menderita.

\section{DAFTAR KEPUSTAKAAN}

Bouyer, Louis, The Eucharist. Theology and Spirituality of the Eucharistic Prayer. Regensburg: University of Notre Dame Press, 1968.

Budde, Achim, Die ägyptische Basilios-Anaphora. Text, Kommentar, Geschichte. Münster: Aschendorff, 2004.

Bugnini, Anibale, Die Liturgiereform 1948-1975. Zeugnis und Testament. Deutsche Ausgabe herausgegebene von Johannes Wagner unter Mitarbeit von Francois Raas. Freiburg: Herder, 1988.

“Doa Syukur Agung Pribumi”. Bahan Studi. Solo: PWI Liturgi, 1975.

"Doa Syukur Agung Indonesia Tercinta". Surakarta: PWI Liturgi, 1976.

Edwards, Denis, Ecology at the Heart of Faith. The Change of Heart that Leads to a New Way of Living on Earth. Maryknoll: Orbis Books, 2011.

Griechische Liturgien, Übersetzt von Remigius Storf. Kempten, 1912.

Groß, Walter, “Die Gottebenbildlichkeit des Menschen im Kontext der

Priesterschrift", Theologische Quartalschrift 161 (1981): 244-261.

Heinemann, Joseph, Prayer in the Talmud. Form and Patterns. Berlin: De Gruyter,1977.

Jasper, R.C.D. and Cuming, G.J., Prayer of the Eucharist. Early and Reformed. Collegeville: Liturgical Press, 1990.

Keenan, Joseph, "The Importance of the Creation Motif in an Eucharistic Prayer", Worship 53 (1978): 341-346.

Mazza, Enrico, The Eucharistic Prayers of the Roman Rite. Collegeville: Liturgical Press, 1984.

Meßner, Reinhard, Einführung in die Liturgiewissenschaft, cet. Ke 2. Paderborn: Ferdinand Schöningh, 2009.

"Mewartakan Kabar Baik di Tengah Krisis Lingkungan Hidup". Bulan Kitab Suci Nasional. Jakarta: Lembaga Biblika Indonesia, 2019.

Müller, Jörg, “Das Leben neu geschaffen. Das Ineinander von Schöpfung und Erlösung im Eucharistischen Hochgebet", Heiliger Dienst 71 (2017): 90-99.

Niederwimmer, Kurt, Didache. Vandenkoeck: Göttingen, 1989.

Prex Eucharistica, Textus a variis liturgiis antiquiribus selecti, diedit oleh Anton 
Hänggi - Irmgard Pahl. Fribourg: Universitätsverlag, 1968.

Probst, Manfred, "Das Schöpfungsmotiv im Eucharistischen Hochgebet", Liturgisches Jahrbuch 3 (1981): 129-144.

Talley, Thomas J., "The Creation Theme in Eucharistic Prayer", dalam Creation and Liturgy (In Honor of H. Boone Porter), ed. Ralph N. McMichael Jr. Washington, 1993: 13-27.

Waibel, Artur, "Das Eucharistische Hochgebet in Indonesien. Episoden vom anderen Ende der Welt", dalam Stefan Böntert (hg.), Gemeinschaft der Eucharistiefeier im ökumenischen Gespräch, ed. Stefan Böntert. Regensburg: Friedrich Pustet, 2015.

Witvliet, John D., "The Anaphora of St. James”, dalam Essay on Early Eastern Eucharistic Prayers, ed. Paul P. Bradshaw. Collegeville: Liturgical Press, 1997: 153-172.

Vagaggini, Cipriano, The Canon of the Mass and Liturgical Reform. Alba House: London, 1967. 